\title{
POLITICAL WILL AND ANTICORRUPTION CRUSADE MANAGEMENT IN NIGERIA
}

\author{
John N. N. Ugoani \\ College of Management and Social Sciences, Rhema University, \\ Nigeria \\ E-mail: drjohnugoani@yahoo.com
}

\section{ABSTRACT}

Accept: 13/10/2015

Corruption in all ramifications has continued to jeopardize the efforts of governments in forging national unity, infrastructural development and in most cases, leaving the majority of a nation's citizens to live in absolute poverty. The phenomenon has persisted in many countries mostly due to weak political will or the lack of it necessary to curb the menace. In its simplest form corruption reflects the use of public office for private gain. As a remedy to this there should be a demonstration of credible intent by political leaders, stakeholders groups to attack perceived causes or effects of corruption at a systemic level. This demonstration of credible capacity reflects political will. The political will to curb corruption is also the political will to pursue other goals like good governance and national unity. Political will is not equivalent to political manifesto rhetoric or pressure group statements. Rather, it is the manifestation of a robust system of checks and balances and strong political institutions for combating corruption and promoting good governance as well as restoring trust and confidence in democratic politics. Gowon's proposal reflects strong political will for good governance, because, if political will is to be more than just a slogan, it must be understood in a broad context. This reinforces the believe that if there is an absence of political will at the top, there will be a general lack of commitment to combat corruption, and pursue other important national goals as political development and poverty reduction. The exploratory research design was adopted for the study. 
Secondary data were generated through a format designed by the investigator for the purpose of the study. Because of the sensitive nature of the study primary data were also generate through a Liker-type questionnaire to supplement the secondary data. Data generated were analyzed through descriptive and $X^{2}$ statistics and presented in tables with absolute figures capable of easy understanding and further analysis. It was found that political will is essential in anticorruption crusade management in Nigeria, and has the reciprocal dimension of providing the incentives for good governance of any nation.

Keywords: Reciprocal dimension; A robust system of checks and balances; promoting good governance; Restoring trust and confidence; Democratic politics; Rule out disintegration, Wahala.

\section{INTRODUCTION}

Political will involves the demonstration of genuine aspiration of political leaders and significant stakeholders to check perceived causes or effects of corruption at a systemic level in society. Kpundeh (1999) posits that political will is a critical starting point for sustainable and effective anti-corruption strategies and programmes.

According to him, the lack of political will to systematically fight corruption allowed abusive practices to continue and eventually became a way of life for Sierra Leoneans under former Presidents Stevens, Momoh, and Strasser. He states that commissions of inquiry in that country showed that corrupt practices led to the ravaging of the treasury and contributed to the economic despondency of the country.

Corruption in its simplest terms is the abuse of power, most often for personal gain or for the benefit of a group to which one owes allegiance (STAPENHURST; SEDIGH, 1999). Corruption is a destroyer; it corrodes the democratic ethos, spreads its filth and eventually imperils democracy.

If left alone, corruption will spread, multiply, intensify, systemize and eventually institutionalize itself, thereby becoming the norm and no longer the exception (UNIAMIKOGBO, 2007). Therefore, political will is seen as the manifestation of a robust system of checks and balances and strong political institutions for combating 
DOI: 10.14807/ijmp.v7i1.382

corruption and promoting good governance as well as restoring trust and confidence in democratic politics.

According to Hopkinson and Pelizzo (2006), to curb corruption effectively, the commitment of government and parliament is above all required. If there is an absence of political will at the top, there will be a general lack of commitment to enforce laws and punish the corrupt. Almost all national anti-corruption agencies point to political will as the main precondition for their effective operation. For effective anti-corruption crusade, there must be political will at the highest level, because malpractice at any level will undermine trust in the political system as a whole.

Marshall (2006) posits that leadership is necessary but not a sufficient condition for controlling corruption, if for no other reason than that tackling corruption can unleash opposition to reform. Therefore, Kpundeh and Dininio (2006) believe that political will, as it applies to anti-corruption crusade is most effective when it is institutionalized and not dependent on the personality and intentions of a particular individual.

Accordingly, reformers can promote institutionalization of political will by establishing and equipping political institutions with adequate autonomy, authority, resources, and qualified manpower. Such institutionalization grows and develops a forum of mutually reinforcing accountability and transparency. The political will to reduce corruption has much in common with the political will to pursue any other goal, such as infrastructure development and poverty reduction.

Political will must be given space to grow from within a political system and eventually becomes an integral part of political, social and economic processes. Without the institutionalization of political will, wedging any war against corruption will be an exercise in futility. For example, despite the anticorruption rhetorics in Nigeria since the military regime, and up to the present democratic experiment, and the passage into law of the Corrupt Practices and Other Related Offences Act during the first tenure of Obasanjo's Presidency, the wahala of massive corruption still persists in Nigeria.

Probably because of the lack of political will to check corruption in Nigeria, Presidents, Governors, legislators, including local government Chairmen and 
DOI: 10.14807/ijmp.v7i1.382

councilors, automatically become billionaires once in office and even after leaving political office. The same applies to ministers, commissioners and sundry government officials. This happens at the detriment of infrastructural development, unemployment and absolute poverty. It is estimated that over 70 percent of Nigerians live below the poverty level (UGOANI, 2015).

In all efforts to combat corruption, the commitment of elected representatives and other public officials is pivotal. According to Staphenhurst and Sedigh (1999) if those who govern a society lack the political will to refrain from corruption and institute change, real reform is difficult to undertake and virtually impossible to sustain.

In addition, pressure for reform that stems from the lower ranks of the bureaucracy can be frustrated by the absence of political will or interest among higher level public servants and political office holders. Political will is critical to fight corruption in Nigeria because the trickle down development strategies is insufficient.

Fighting corruption, human capital development, through informal and formal employment generation and rapid advances in public services must remain a key plank of development strategies (MANUEL, 2003). Corruption may be defined as the use of public office for private gain. It can take on a multitude of faces; its scale can be grand or petty.

Corruption may be classified into three broad types: state capture which is often equated with grand corruption or political corruption, patronage and nepotism, and administrative corruption. While these forms of corruption overlap significantly, they are not equivalent. Patronage is politically motivated, and administrative corruption can involve huge sums like commissions from huge rigged contracts.

Grand corruption refers to corruption that involves extraordinary large side payments; political corruption refers to favours exchanged for support, financial or otherwise, to buttress or sustain the political power of individuals or groups, such as illegal campaign contributions. Kleptocracy and cronyism are other forms of political corruption.

In these cases, political leaders use the organ of the state to enrich themselves, children, family members, friends and associates through legal and illegal means. (CAMPOS; BHARGERG, 2007). It is curious that despite acceptance 
DOI: 10.14807/ijmp.v7i1.382

by governments like in Nigeria and other late developing democracies that corruption exists and is serious, there is always a general lack of political will to implement recommendations and the necessary legislation to combat corruption (EMMANUEL; OMOMIA, 2012; HOPKINSON; PELIZZO, 2006) Marshall (2006) insists that corruption is a clear threat to development, democracy, and international security.

It distorts economic and social development and subverts political decisionmaking, stunting growth and creating political instability. Corruption is closely linked to failing public institutions and failed public policies, undermining the legitimacy of governments at all levels. It drains national finances, acting as a major disincentive to securing foreign investment, as well as destroying the work ethic of the citizens.

Corruption can have a profoundly negative impact on patriotism and commitment to the national goals and ideals, and it also deepens poverty. These factors combine to show that combating corruption is an issue for both national regional and global authorities. The monumental corruption in Nigeria today attracts global attention, to the extent that the G.7 leaders of the world believe that the Nigerian economy is mismanaged (TAIWO-OBALONYE, 2015).

Straw (2014) posits that there must be transparency in governance at all levels in order to effectively tackle the menace of corruption in Nigeria. A former British Foreign Secretary, he also suggests that there must be incorruptible judiciary to give appropriate penalties against corrupt officials to ensure that the war against corruption in Nigeria succeeds - (OMOTOSO, 2013; OMOTOSO, 2011; OGUNWALE, 2012; EMMANUEL, 2014; OBIJIOFOR, 2013; ALLI, 2012). Corruption disrupts governance, reduces the provisions of services by the government and its institutions (UGURU; IBEOGU, 2014).

\subsection{Statement of the problem}

There is significant empirical evidence that corruption exists in Nigeria, but there is no evidence that there is the political will to check it. The wahala of serious allegations of massive corruption in government and the oil and gas industry is monumental.

Corruption appears to be flowing unquenchably like the River Niger in the oil and gas industry from where the nation derives over 90 percent of its revenue. Also people in government become billionaires overnight in a country with over 8000 
DOI: 10.14807/ijmp.v7i1.382

abandoned projects that would require over N5trn to complete in over 30 years, where major public enterprises are given away on political patronage without proper valuation, and where the majority of the citizens live in absolute poverty.

A country where 50 percent of the federating states despite heavy borrowings cannot pay workers salaries, but where the ex-presidents, ex-governors, ex-this and ex-that live like emperors, must be a thoroughly corrupt country. A country with leaders who parade shining certificates but without moral capacity and political will to deal with corruption and promote good governance. (OMOTOSO, 2013; EMMANUEL, 2014; GABRIEL, 2015; JEYIFO, 2013; OJO, 2015; OLABIYI, 2015; AMODU, 2015; DAILY SUN NEWS, 2015; UGWUANYI, 2011; DAKA, 2012; ORINTUNSIN, 2014).

Without the benefit of accurate statistics, it is evident that from organized media reports there could be thousands of pending corruption allegations of which the political leaders lack the political will to prosecute to conclusion. Prominent among them includes the ground breaking mega oil subsidy scam involving about $\$ 2.58$ trn.

Government remains helpless in this case that has helped in securing a permanent seat for Nigeria as one of the most corrupt countries in the world. Corruption cases such as loading cash in private jets across the world, mutilated local currency theft, tax evasion by oil and gas companies, multiple cases of unremitted billions of dollars to the federation account, steeling of pension cash, giving and receiving bribes, wasteful budgeting, remain among the many corrupt practices in Nigeria. Nothing more is required more than political will on the part of political leaders to push the frontiers of corruption backwards. (ABUBEKAR; MUSARI, 2015; TAIWO-OBALONYE, 2015; MERNYI, 2015A; TSA, 2015; MERNYI, 2015B; OJIABOR, 2012; NWOSU, 2013; ALLI, 2013; ISA, 2014; ERIYE, 2012; ISA, 2014B; NZESH, 2014; ONANUGA, 2012; ALLI, 2012B; OLUWASEGUN; ANOFI, 2013; MALOGO, 2013)

\subsection{Objective of the study}

The study was designed to explore the relevance of political will in anticorruption crusade management in Nigeria. 
DOI: 10.14807/ijmp.v7i1.382

\subsection{Significance of the study}

The study will enable students of public policy and others, researchers, and the general public have insights about the relationship between political will and anticorruption crusade management.

\subsection{Delimitation of the study}

The study was delimited to Abia State, South-East Nigeria. Abia State is one of the 36 States in Nigeria and it was assumed that the views of the people in Abia State will represent the views of the people in Nigeria.

\subsection{Limitations of the study}

The study was constrained by lack of statistics on corruption cases and current literature in the area of study. However, these important limitations did not impair the academic focus of the study.

\subsection{Hypotheses}

To achieve the objective of the study, the following hypotheses were posed, and test at 0.05 level of significance:

Ho: There is no relationship between political will and anticorruption crusade management

$\mathrm{Hi}$ There is a relationship between political will and anticorruption crusade management.

\section{LITERATURE REVIEW}

Before the present administration, preceding administrations in Nigeria had successively instituted legal instruments, measures and policies designed to combat corruption in the country. According to Uniamikogbo (2007) these remedial measures did not achieve the desired results to prohibit and prescribe punishment for corrupt practices.

The Corrupt Practices and Other Related Offences Act 2000 was the first to be passed into law by the Obasanjo Presidency, while the Independent Corrupt Practices and Other Related Offences Commission (ICPC) were inaugurated on the 29th of September 2000. There is also, the Economic and Financial Crimes 
DOI: 10.14807/ijmp.v7i1.382

Commission (EFCC) charged with the responsibility for the enforcement of all economic and financial crimes, laws, among other things.

Despite the anxiety of government over corruption expressed through these reform programmes political will is on a long holiday, and corruption continues to flourish like the morning rose. As it grows, it manifests in many ways, like infrastructural decay, poverty, etc.

\subsection{Corruption and Infrastructural decay}

The idea of dispensing with public enterprises was partly due to corruption and inefficiency that led to dwindling resources. For example, the reform in the telecommunications sector was motivated by the inability of government to continue to fund public enterprises being mismanaged and to reduce corruption.

Public sector giants like the Power Holding Company of Nigeria (PHCN) was riddled with corruption and inefficiency that led to its dismemberment along geopolitical zones for more reasons of political patronage and expediency. According to Uniamikogbo (2007) in 1999, the Federal Government owned a total of 590 Public Enterprises (PEs) worth about US\$100bn as at 1996.

As a result of unproductive investments in and the inefficiency of these enterprises in terms of the quality of services rendered, privatization was introduced as a practical solution. However, as a result of lack of political will, the exercise is today accused of lack of transparency, and has not yielded any meaningful results in terms of employment generation and poverty reduction among the citizens.

The abandonment of over 8000 projects that require over N5trn to complete and without any body accountable for such corruption practices is a display of lack of political will on the part of government to combat corruption. (ORINTUNSIN, 2014; OMOTOSO, 2011; OGUNWALE, 2012; EMMANUEL, 2014; ALLI, 2012; MALOGO, 2012).

At present, the Federal Government fears that the privalitzation of NITEL and MTEL was transparent. The rate of infrastructural decay in Nigeria is alarming. According to Nwachi (2013) a document prepared by a group of research experts, commissioned by the Federal Ministry of Finance listed 30 most corrupt institutions in 
DOI: 10.14807/ijmp.v7i1.382

Nigeria with the police and the defunct Power Holding Company of Nigeria (PHCN) as the most corrupt.

The document which was made available to Independent Corrupt Practices Commission (ICPC) ranked the ministries and parastatals according to their levels of involvement in various corrupt practices in the past. The first and second most corrupt agencies in Nigeria have been and still remain the police and defunct PHCN, respectively.

While the third, fourth, fifth and sixth most corrupt institutions of government are the political parties, the executive arm of federal, state and local governments, members of the national and state assemblies and the court. Others are the Customs, Federal Road Safety Commission, (FRSC) offices of the accountant general at both federal and state levels and water boards.

According to the report, no public service sector is rated, as somewhat or very honest by up to 50 percent. For the ICPC, it was a pointer in the direction to look for corrupt public officials in fulfillment of its mandate but nothing was actually done. Grand corruption cases like the SAGEM, SA. ID Scandal involving about US $\$ 241 \mathrm{~m}$ and the Halliburton scandal involving about US $\$ 182 \mathrm{~m}$ are yet to be disposed off.

This is perhaps due to impunity. Corrupt politicians disobey court orders as a means of staying in office. For example, when a federal high court in Abuja ordered on 2 December 2010, the immediate reinstatements of six suspended members of the House of Representative others served notice of appeal. Bankole did not want the suspended members to return even though the Abuja court had ruled that the continued suspension of the members was a form of "tyranny of the majority".

The parliament is critical for effective anticorruption crusade management. If political will is to be more than just a slogan, it must be understood in a broad context. Particularly where democratic politics is in place or emerging in sustainable ways, political will requires leaders willing to attack corruption and support agencies ready to back them up, reward success, and exact political price for failure or deceit (OBIJIOFOR, 2011; NWACHI, 2013; EFULU, 2015; OBINNA, 2015; OMOMBI, 2015; TAIWO-OHANONYE, 2015; UKEH, 2015).

Corruption in the power sector is yet to be quantified in terms of Naira and Dollar. Despite billions of dollars pumped into the sector in the last sixteen years, 
DOI: 10.14807/ijmp.v7i1.382

Nigerians are yet to record any meaningful improvement in power supply. The senate has now decided to investigate the matter. According to Anuforo (2015) shortly after the exit of President Obansanjo, there were outcries that the Power Sector should be investigated to uncover how over US $\$ 12 \mathrm{bn}$ reportedly spent to upgrade power infrastructure was simply stolen and pocketed by the politicians manning the power ministry.

\subsection{Corruption and Poverty.}

The concept of poverty refers to a situation in which an individual/community/country lacks the capacity to independently secure a decent standard of living or decent quality of life. Specifically, at the individual level poverty is reflected by deprivation and lack of access to basic necessities of life such as adequate food, decent clothing, suitable business, safe drinking water, good education, good medical care, and gainful employment, inability to fulfill social and cultural obligations that are important (OBASI, 2001).

Although poverty is a world wide phenomenon, but the prevalence of the disease is compounded in Nigeria due to corruption. The question of poverty is no longer negotiable in Nigeria of today where 18 out of 36 state governments owe the workers huge salary arrears of up to 3-6 months. Some of the governors of the defaulting states are standing trial on charges of corruption.

Some of them even won fresh elections. There is no political will on the part of government to avoid corruption providing incentives for the actions and inactions of corrupt leaders to deepen poverty through non payment of workers salaries, among others. Economists suggest that the wage system is a fine way of income distribution, it therefore follows that when a huge part of the population in a country does not have regular or steady source of income, it will result to coefficient inequality between the rich and the poor. Corruption can destroy the work ethics of citizens and above all, it deepens poverty (GABRIEL, 2015; MARSHALL, 2006).

Political will is necessary to good governance architecture that connects broad concerns about how economic, social, and political institutions are organized with the specific intention of taking specific steps to reducing corruption and poverty in society. 


\subsection{Lessons from other Countries}

According to Hopkinson and Pelizzo (2006) corruption will always exist, because it cannot be eliminated totally, but can be curbed or controlled. They insist that corruption is regarded as the most significant political challenge in most Central and East European countries. They opine that although corruption is universal, states in transition, where democracy and a market economy have only recently been established, are particularly afflicted.

According to Kpundeh (1999) corruption became a way of life in Sierra Leone during the presidency of Stevens, Momoh and Strasser, not because of lack of anxiety, but due largely to lack of political will by government to check corruption. During the period unscrupulous civil servants, policians, and business people sought to raise their standards of living through bribery, which in some cases became more accurately described as extortion.

A lack of political will resulted in the absence of adequate sanctions or the failure to enforce them. People had to weigh the advantages and disadvantages of following the rules and decide how they are best served. Thus, if the benefits outweigh the costs, more people than not chose wrongdoing as a customary way of supplementing their income. In this way, corruption was institutionalized in Sierra Leone. Corruption is no longer a local matter but a transnational phenomenon that affects all societies, and economies, making international cooperation to prevent and control it essential (WILLIAMS, 2006).

Kaufmann (1997) points to the case of Kenya, where prevalent corruption and its negative macroeconomic consequences compelled the International Monetary Fund to suspend its lending in 1997. In the same year, on the heels of mounting pressure from civil society and the international community the president of Kenya issued pronouncements against corruption. As a follow-up to the president's remarks, the office of the Attorney General released the following statements.

The Government has this morning formed an anticorruption squad to look into the conduct of the anticorruption commission, which has been overseeing the anticorruption taskforce, which was earlier set up to investigate the affairs of a government adhoc committee appointed earlier this year to look into the issue of 
DOI: 10.14807/ijmp.v7i1.382

high-level corruption among corrupt Government Officers. Kaufmann (1997) posits that this type of example may be an extreme case of how not to address the problem of corruption. Unfortunately many similar statements had been reported in countries in Asia, Latin America and the former Soviet Union.

It is almost usual for corrupt politicians to engage in rhetoric about eliminating corruption and the pressure from the donor community. Nevertheless, statements like the one from Kenya represent weak political will, because it never showed exactly the direction of government. In response to pressures for political will, uncommitted political leaders often show weak political will, which is another constraint to weeding out corruption.

Such anticorruption rhetoric as a result of weak political will has been a routine feature of politics invariably less as a precursor to longer-term reform, than as a means to diffuse opposition, placate external agencies, and secure political office. In this context, anticorruption campaigns then degenerate into political rhetoric designed more to appease foreign donor and international financial institutions than to address the major issue of combating corruption.

Olowu (1993) posits that in Nigeria political actors, often talk of accountability and integrity but this by itself does not translate into a genuine commitment to detect and panelize unethical behavior. Even when anticorruption agencies are created, they are usually denied the resources needed to achieve their stated purpose.

In many cases the codes of ethics they are asked to enforce have no broadbased popular understanding or support. Furthermore, "the preoccupation with panic measures and the creation of adhoc panels and tribunals to replace non-functioning legal institutions for ensuring public accountability have not been particularly helpful", Olowu (1993) also posits that in the former Soviet Union, anticorruption legislation was promulgated that required government officials to make public statements of personal networth.

However, the legislation was not accompanied by provisions for verifying information or sanctioning the submission of false statements. As a result, public cynicism intensified when some of the nation's wealthiest individuals reported absurdly low networth statements, contradicted by their extravagant lifestyles and possessions. 
DOI: 10.14807/ijmp.v7i1.382

Fatigues, fear, resignation, and opportunism may diminish the commitment of political reformers and attenuate political will. As a result, anticorruption may break down, and corruption continues. Examples abound around the world of exploitative rulers who have hidden their motives behind a façade of cosmetic measures or wellintended reformers who have engineered their own destruction through ineffective strategies.

In the light of these traps, proponents of political reform processes must look at several indicators that can serve as demonstrations of political will. Because of weak political will or lack of it, the Presidency of Momoh in the Sierra Leone was accused of being drenched in sectionalism, tribalism, favouritism, nepotism, incompetence, ineptitude, treachery, indolence, wining, dining and womanizing, which inflicted the severest mismanagement of the affairs of the country (WILLIAM, 1995; SIERRA LEONE NEWS AGENCIES, 1992; WILLIAM, 1996a, 1996b).

One of the greatest dangers of corruption is that it weakens trust in government. It undermines the legitimacy of political leaders and their institutions. According to Kpundeh (1999) revelations of misdeeds have led people to believe that public officials wish only to get rich at their expense, that the country's resources are being wasted and stolen, and that-bribery is the quickest way to get things done.

These attitudes have led to serious crises of confidence in both public officials and public institutions. He emphasizes that corruption adversely affects democratic processes. Cases of money disappearing from governmental treasuries are indications of the disastrous effects of corruption to democratic institutions, and economic mismanagement create poverty.

Good political will leads to good governance because it has a reciprocal dimension which entails efficient and effective reciprocity between rulers and the ruled with responsiveness incumbent upon the government (KPUNDEH, 1992, 1993, 1995).

\section{RESEARCH METHODOLOGY}

\subsection{Research design}

Exploratory research design was used for the study. Exploratory research design is used to study and gain insight into a situation that is not very clear and that 
DOI: 10.14807/ijmp.v7i1.382

has not attracted serious investigation and research in the past. The objective of exploratory research is to define a problem more succinctly and develop course or courses of action that will lead to its solution. The nature of exploratory research requires the use of a flexible research process. It is evolutionary and historical in nature and it rarely involves the employment of large samples or use of structured questionnaire. A typical example of an exploratory research is a case study of a problem situation (ASIKA, 2004).

\subsection{Population and samples}

The study population is comprised of the people in Nigeria. The sample of the study was selected through the simple random sampling method. The sample size was determined using the Yamane's technique.

\subsection{Data collection method.}

Data were collected from both primary and secondary sources. Secondary data were collected using a schedule titled "Corruption Index Format" (CIFO). The CIFO was designed with five columns. Primary data were generated through a 7point Likert-type questionnaire. Previous investigations have found the Likert scale questionnaire to be acceptably internally consistent, with a Cronbach's Alpha value of about .82. Content and construct validity has also been established (MADSEN, 2003a). Data collected were supplemented, complemented and validated through each other by discussions, interviews, and observations.

\subsection{Method of data analysis}

Data were analyzed through descriptive and Chi-square statistical methods. The results were presented in tables capable of understanding and re-analysis.

\section{PRESENTATION OF RESULTS}

Table1: Selected Reported Outstanding Corruption Allegation Cases in Nigeria As At 2015

\begin{tabular}{|l|l|l|l|l|l|}
\hline S/ & Amount & Secondary Source & Brief Description & Status \\
\cline { 2 - 5 } & $\$$ & N & $\begin{array}{l}\text { Guardian vol. 31, No. } \\
13319\end{array}$ & $\begin{array}{l}\text { Private loaded with cash seized in South } \\
\text { Africa }\end{array}$ & Pending \\
\hline 1 & $\$ 9.7 \mathrm{~m}$ & $\begin{array}{l}\text { Daily sun, vol. 10, No. } \\
3161\end{array}$ & Tax evasion by oil \& gas companies & Pending \\
\hline 2 & $\$ 7.5 \mathrm{bn}$ & $\begin{array}{l}\text { Daily sun, vol. 10, No. } \\
3167\end{array}$ & Amount unremitted to NEITL by IOCs & Pending \\
\hline 3 & $\$ 9.8 \mathrm{bn}$ & Daily sun vol. 10, No. & Total amount due to FGN for 2012 not & Pending \\
\hline 4 & $\$ 11.6 \mathrm{~b}$ & &
\end{tabular}


INDEPENDENT JOURNAL OF MANAGEMENT \& PRODUCTION (IJM\&P)

http://www.ijmp.jor.br

v. 7, n. 1, January - March 2016

ISSN: 2236-269X

DOI: 10.14807/ijmp.v7i1.382

\begin{tabular}{|c|c|c|c|c|c|}
\hline & $\mathrm{n}$ & & 3161 & paid by oil \& gas industry. & \\
\hline 5 & & N8bn & $\begin{array}{l}\text { Daily sun, vol. 10, No. } \\
3165\end{array}$ & $\begin{array}{l}\text { Part of local currency scam involving } \\
\text { CBN officials }\end{array}$ & Pending \\
\hline 6 & & N15bn & $\begin{array}{l}\text { Daily sun, vol. 10, No. } \\
3165\end{array}$ & $\begin{array}{l}\text { Corruption charge against Nyako, others } \\
\text { by EFCC }\end{array}$ & Pending \\
\hline 7 & & N62bn & $\begin{array}{l}\text { Sunday sun, vol. 10, } \\
\text { No. } 628\end{array}$ & $\begin{array}{l}\text { Corruption charge against Orji's, son by } \\
\text { EFCC }\end{array}$ & Pending \\
\hline 8 & $\$ 8.8 \mathrm{~m}$ & & $\begin{array}{l}\text { Daily sun, vol. } 10, \text { No. } \\
3165\end{array}$ & $\begin{array}{l}\text { Corruption charge against oil \& gas Chief } \\
\text { Deepak, K. }\end{array}$ & Pending \\
\hline 9 & $\begin{array}{l}\$ 2,58 \text { tr } \\
\mathrm{n}\end{array}$ & & $\begin{array}{l}\text { Nation vol. 7, No. } \\
2553\end{array}$ & Mega-oil subsidy scam since $2011 / 2013$ & Pending \\
\hline 10 & $\$ 30$ trn & & $\begin{array}{l}\text { Vanguard, vol. 25, No. } \\
62332\end{array}$ & $\begin{array}{l}\text { Allegations of economic mess by C.C } \\
\text { Soludo }\end{array}$ & $\begin{array}{l}\text { No clearer } \\
\text { information }\end{array}$ \\
\hline 11 & $\$ 20 b n$ & & $\begin{array}{l}\text { Nation vol. 8, No. } \\
2701\end{array}$ & $\begin{array}{l}\text { Allegations of unremitted money against } \\
\text { NNPC by CBN governor }\end{array}$ & Pending \\
\hline 12 & $\$ 49 b n$ & & $\begin{array}{l}\text { Nation vol. 8, No. } \\
2701\end{array}$ & $\begin{array}{l}\text { Allegations of missing money against } \\
\text { NNPC by CBN governor }\end{array}$ & Pending \\
\hline 13 & & $\begin{array}{l}\text { N500b } \\
\mathrm{n}\end{array}$ & $\begin{array}{l}\text { Nation vol. 8, No. } \\
2701\end{array}$ & Allegations of missing SURE-P money & $\begin{array}{l}\text { No clearer } \\
\text { details }\end{array}$ \\
\hline 14 & & N1.3trn & $\begin{array}{l}\text { National vol. } 7 \text {, No. } \\
2316\end{array}$ & Allegations of debt owed NNPC by FGN & Pending \\
\hline 15 & $\begin{array}{l}\$ 32.3 b \\
n\end{array}$ & & $\begin{array}{l}\text { Daily sun, vol. } 10, \text { No. } \\
3150\end{array}$ & $\begin{array}{l}\text { Allegations of mismanagement of public } \\
\text { fund by FG }\end{array}$ & Pending \\
\hline 16 & $\$ 13 b n$ & & $\begin{array}{l}\text { Daily sun, vol. } 10, \text { No. } \\
2761\end{array}$ & $\begin{array}{l}\text { Allegations of remittance of only } \$ 17 \text { out } \\
\text { of } \$ 20 \text { bn oil money by NNPC }\end{array}$ & Pending \\
\hline 17 & & N22bn & $\begin{array}{l}\text { Nation vol. } 8, \text { No. } \\
2695\end{array}$ & $\begin{array}{l}\text { Allegations of sum not remitted to FG by } \\
\text { NNPC - Sanusi }\end{array}$ & Pending \\
\hline 18 & & N24bn & $\begin{array}{l}\text { New telegraph vol. } 1 \text {, } \\
\text { No. } 23\end{array}$ & $\begin{array}{l}\text { Allegations of missing police pension } \\
\text { money }\end{array}$ & $\begin{array}{l}\text { Defended } \\
\text { by CME }\end{array}$ \\
\hline 19 & $\$ 1.3 \operatorname{trn}$ & & $\begin{array}{l}\text { Nation, vol. } 7 \text {, No. } \\
2316\end{array}$ & Govt. owes us $\$ 1.3 \operatorname{trn}$ on subsidy & Pending \\
\hline 20 & $\$ 43 m$ & & $\begin{array}{l}\text { Nation, Dec. 27, pp. } \\
15\end{array}$ & Allegation of profiteering on aviation fuel & $\begin{array}{l}\text { No clearer } \\
\text { details }\end{array}$ \\
\hline 21 & $\$ 1.7$ trn & & $\begin{array}{l}\text { Guardian vol. } 29, \text { No. } \\
12185\end{array}$ & $\begin{array}{l}\text { Refund of amount misapplied by NNPC } \\
\text { and others in the oil subsidy scam }\end{array}$ & $\begin{array}{l}\text { Report not } \\
\text { yet } \\
\text { adopted. } \\
\text { No refund } \\
\text { made }\end{array}$ \\
\hline 22 & $\begin{array}{l}\$ 62000 \\
0\end{array}$ & & $\begin{array}{l}\text { Nation vol. 06, No. } \\
2170\end{array}$ & $\begin{array}{l}\text { Bribery allegation against Lawan by } \\
\text { Otedola }\end{array}$ & $\begin{array}{l}\text { No clearer } \\
\text { news again }\end{array}$ \\
\hline 23 & & N118n & $\begin{array}{l}\text { New telegraph, vol. } 1 \text {, } \\
\text { No. } 23\end{array}$ & $\begin{array}{l}\text { Amount allegedly recovered by FMOF } \\
\text { through ghost workers elimination }\end{array}$ & No news \\
\hline 24 & & N295b & $\begin{array}{l}\text { New telegraph vol. } 1 \text {, } \\
\text { No. } 2\end{array}$ & Allegations of wasteful budget allocation & No news \\
\hline 25 & & N4,6bn & $\begin{array}{l}\text { Nation, vol. 7, No. } \\
2270\end{array}$ & $\begin{array}{l}\text { EFCC arraigns } 13 \text { new marketers over } \\
\text { oil subsidy fraud }\end{array}$ & No news \\
\hline 26 & & $\begin{array}{l}\text { N382b } \\
n\end{array}$ & $\begin{array}{l}\text { Nation, Vol. 7, No. } \\
2302\end{array}$ & $\begin{array}{l}\text { Fuel subsidy fraud: EFCC grills } 11 \text { more } \\
\text { marketers }\end{array}$ & No news \\
\hline 27 & & $\mathrm{~N} 109 \mathrm{~m}$ & $\begin{array}{l}\text { Nation Vol. 7, No. } \\
2283\end{array}$ & Alleged N109m pension fraud & In court \\
\hline 28 & & $\begin{array}{l}\text { N750b } \\
\mathrm{n}\end{array}$ & $\begin{array}{l}\text { Nation vol. 8, No. } \\
2701\end{array}$ & $\begin{array}{l}\text { Allegations of annual oil money theft by } \\
\text { Tambuwal }\end{array}$ & No news \\
\hline 29 & & $\mathrm{~N} 255 \mathrm{~m}$ & $\begin{array}{l}\text { Nation vol. } 8 \text {, No. } \\
2701\end{array}$ & $\begin{array}{l}\text { Allegations of poor handling of bullet } \\
\text { proof car scam by Tambuwal }\end{array}$ & No news \\
\hline 30 & & N5trn & $\begin{array}{l}\text { Nation, vol. 9, No. } \\
3080\end{array}$ & $\begin{array}{l}\text { Alleged cost of abandoned projects by } \\
\text { N.A Darma, Fmr director NPC }\end{array}$ & No news \\
\hline 31 & $\begin{array}{l}\$ 1182 \\
\mathrm{~m}\end{array}$ & & $\begin{array}{l}\text { Sunday Vanguard, vol. } \\
24, \text { No. } 1483\end{array}$ & Bribery case against Halliburton & $\begin{array}{l}\text { Still } \\
\text { pending }\end{array}$ \\
\hline
\end{tabular}


INDEPENDENT JOURNAL OF MANAGEMENT \& PRODUCTION (IJM\&P)

http://www.ijmp.jor.br

v. 7, n. 1, January - March 2016

ISSN: 2236-269X

DOI: 10.14807/ijmp.v7i1.382

\begin{tabular}{|l|l|l|l|l|l|}
\hline 32 & & $\begin{array}{l}\text { N474b } \\
\mathrm{n}\end{array}$ & $\begin{array}{l}\text { Daily Sun, vol. 10, No. } \\
3192\end{array}$ & $\begin{array}{l}\text { Allegations of bureaucratic corruption } \\
\text { against ex-gov. Senator T.A Orji of Abia } \\
\text { State }\end{array}$ & $\begin{array}{l}\text { No. Clearer } \\
\text { direction } \\
\text { yet }\end{array}$ \\
\hline 33 & $\begin{array}{l}\text { Multimil } \\
\text { lion }\end{array}$ & $\begin{array}{l}\text { Multibill } \\
\text { ion }\end{array}$ & $\begin{array}{l}\text { Daily Sun, Vol. 10, No. } \\
3211\end{array}$ & $\begin{array}{l}\text { Perceptions of lack of transparency in } \\
\text { the liquidation of NITEL/MTEL }\end{array}$ & $\begin{array}{l}\text { To be } \\
\text { probed by } \\
\text { the FG }\end{array}$ \\
\hline 34 & $\begin{array}{l}\text { N3.180 } \\
\text { bn }\end{array}$ & $\begin{array}{l}\text { Daily Sun, vol. 10, No. } \\
3211\end{array}$ & $\begin{array}{l}\text { Allegations of misappropriation of } \\
\text { N3.180bn MDG's funds by the SSAp }\end{array}$ & $\begin{array}{l}\text { Fresh } \\
\text { petition by } \\
\text { Efulu }\end{array}$ \\
\hline 35 & $\begin{array}{l}\text { US\$24 } \\
1 \mathrm{~m}\end{array}$ & $\begin{array}{l}\text { Energy Today, Vol. 2, } \\
\text { No. 15, pp: 7 }\end{array}$ & SAGEM, SA ID Card Scandal & $\begin{array}{l}\text { In the } \\
\text { cooler }\end{array}$ \\
\hline 36 & N1trn & $\begin{array}{l}\text { Daily Sun, vol. 10, No. } \\
3216, \text { pp:12 }\end{array}$ & $\begin{array}{l}\text { Allegations of diversion of N1trn against } \\
\text { the EFCC boss }\end{array}$ & $\begin{array}{l}\text { Before the } \\
\text { senate } \\
\text { Ethics } \\
\text { committee }\end{array}$ \\
\hline 37 & b183.7 & $\begin{array}{l}\text { Daily Sun vol. 10, No } \\
3216, \text { pp: 46 }\end{array}$ & $\begin{array}{l}\text { Allegations of misappropriation between } \\
\text { 2008/12 at NDDC }\end{array}$ & $\begin{array}{l}\text { before the } \\
\text { presidency }\end{array}$ \\
\hline 38 & $\begin{array}{l}\text { N567b } \\
\text { n }\end{array}$ & $\begin{array}{l}\text { Daily Sun, vol. 10, No. } \\
3218, \text { pp 49 }\end{array}$ & $\begin{array}{l}\text { Allegations of illegal spending by CG } \\
\text { NCS }\end{array}$ & $\begin{array}{l}\text { Petition } \\
\text { before the } \\
\text { presidency }\end{array}$ \\
\hline 39 & $\begin{array}{l}\text { Multibill } \\
\text { ion } \\
\text { naira }\end{array}$ & $\begin{array}{l}\text { Daily Sun, vol. 10, No. } \\
3218 \text { pp. 5 }\end{array}$ & $\begin{array}{l}\text { Allegations of fraud against SGF over } \\
\text { Centenary city project }\end{array}$ & $\begin{array}{l}\text { Petition } \\
\text { before the } \\
\text { presidency }\end{array}$ \\
\hline 40 & $\begin{array}{l}\text { US } \$ 12 \\
\text { bn }\end{array}$ & $\begin{array}{l}\text { The Guardian, vol. 32, } \\
\text { No. 13402 }\end{array}$ & $\begin{array}{l}\text { Allegations of stealing US } \$ 12 b n \text { meant } \\
\text { for the power sector by politicians }\end{array}$ & $\begin{array}{l}\text { Under } \\
\text { senate } \\
\text { probe. }\end{array}$ \\
\hline
\end{tabular}

Source: Fieldwork, 2015.

Table 2: $\quad$ History of some Abandoned Projects in Nigeria As At 2015

\begin{tabular}{|c|c|c|c|c|c|c|}
\hline \multirow[b]{2}{*}{ S/N } & \multirow{2}{*}{ Brief description } & \multicolumn{2}{|c|}{ Amount } & \multirow{2}{*}{$\begin{array}{l}\text { Secondary } \\
\text { source }\end{array}$} & \multirow{2}{*}{ Status } & \multirow{2}{*}{ Remarks } \\
\hline & & $\$$ & $\mathbf{N}$ & & & \\
\hline 1 & $\begin{array}{l}\text { As at } 19934000 \\
\text { federal government } \\
\text { abandoned projects } \\
\text { all over Nigeria }\end{array}$ & & $300 \mathrm{bn}$ & $\begin{array}{l}\text { Guardian vol. } 29 \\
\text { No. } 11922- \\
2011-12-8-\end{array}$ & $\begin{array}{l}\text { Abandoned } \\
\text { projects }\end{array}$ & $\begin{array}{l}\text { Houses, schools, } \\
\text { roads, bridges, } \\
\text { railway tracks, } \\
\text { dams, tunnels, air } \\
\text { ports, seaports, } \\
\text { etc }\end{array}$ \\
\hline 2 & $\begin{array}{l}\text { Between } 1986 \text { and } \\
200914 \text { abandoned } \\
\text { road projects in Ondo } \\
\text { State }\end{array}$ & & $2.1 \mathrm{bn}$ & $\begin{array}{l}\text { Guardian vol. } \\
29, \text { No } 11922 . \\
12-8-2011\end{array}$ & $\begin{array}{l}\text { Abandoned } \\
\text { projects }\end{array}$ & $\begin{array}{l}\text { Roads, houses, } \\
\text { churches, etc. }\end{array}$ \\
\hline 3 & $\begin{array}{l}\text { In } 2012 \text { the high } \\
\text { profile Lagos - Ibadan } \\
\text { Expressway project } \\
\text { was cancelled by the } \\
\text { federal government }\end{array}$ & & $89.53 b n$ & $\begin{array}{l}\text { The Nation, vol. } \\
7, \text { No. } 2316\end{array}$ & Not clear & $\begin{array}{l}\text { Allegations of lack } \\
\text { of project finance } \\
\text { and competence. }\end{array}$ \\
\hline 4 & $\begin{array}{l}8000 \text { - abandoned } \\
\text { federal government } \\
\text { projects as at } 2014\end{array}$ & & 5 trn & $\begin{array}{l}\text { The Nation, vol. } \\
9 \text {, No. } 3080\end{array}$ & $\begin{array}{l}\text { No clear } \\
\text { and full } \\
\text { details }\end{array}$ & $\begin{array}{l}\text { Too many } \\
\text { abandoned } \\
\text { projects }\end{array}$ \\
\hline 5 & $\begin{array}{l}\text { Ajaokuta steel } \\
\text { complex }\end{array}$ & $\begin{array}{l}\text { Multi } \\
\text { billion }\end{array}$ & & $\begin{array}{l}\text { Sunday } \\
\text { Vanguard vol. } \\
24, \text { No. } 1479\end{array}$ & $\begin{array}{l}\text { Abandoned } \\
\text { for many } \\
\text { years }\end{array}$ & $\begin{array}{l}\text { Demons are being } \\
\text { blamed }\end{array}$ \\
\hline
\end{tabular}

Source: Fieldwork, 2015 
INDEPENDENT JOURNAL OF MANAGEMENT \& PRODUCTION (IJM\&P)

http://www.ijmp.jor.br

v. 7, n. 1, January - March 2016

ISSN: 2236-269X

DOI: 10.14807/ijmp.v7i1.382

Table 3: List of 18 Out of 36 States In Nigeria Unable To Pay Workers Salaries for Over 3 months as at 29/5/15

\begin{tabular}{|c|c|c|}
\hline $\mathbf{S} / \mathbf{N}$ & Name of state & Remarks \\
\hline 1 & Abia & $\begin{array}{l}\text { Workers lamenting their ugly } \\
\text { plight }\end{array}$ \\
\hline 2 & Akwa lbom & $"$ \\
\hline 3 & Bauchi & $"$ \\
\hline 4 & Benue & $"$ \\
\hline 5 & Cross River & $"$ \\
\hline 6 & Ekiti & $"$ \\
\hline 7 & Imo & " \\
\hline 8 & Jigawa & $"$ \\
\hline 9 & Kano & $"$ \\
\hline 10 & Katsina & $"$ \\
\hline 11 & Kogi & $"$ \\
\hline 12 & Ogun & " \\
\hline 13 & Ondo & $"$ \\
\hline 14 & Osun & " \\
\hline 15 & Oyo & $"$ \\
\hline 16 & Plateau & $"$ \\
\hline 17 & Rivers & " \\
\hline 18 & Zamfara & " \\
\hline
\end{tabular}

Table 4: List of States With External Debts As At 29/5/2015

\begin{tabular}{|l|l|l|c|}
\hline S/N & Name of state & Amount (\$) & Status \\
\hline 1 & Lagos & $\$ 1.087 \mathrm{bn}$ & Outstanding \\
\hline 2 & Kaduna & $\$ 234 \mathrm{~m}$ & $"$ \\
\hline 3 & Cross River & $\$ 131,469 \mathrm{~m}$ & $"$ \\
\hline 4 & Edo & $\$ 123 \mathrm{~m}$ & $"$ \\
\hline 5 & Osun & $\$ 109 \mathrm{~m}$ & $"$ \\
\hline 6 & Bauchi & $\$ 87 \mathrm{~m}$ & $"$ \\
\hline 7 & Enugu & $\$ 62 \mathrm{~m}$ & $"$ \\
\hline 8 & Katsina & $\$ 78 \mathrm{~m}$ & $"$ \\
\hline 9 & Osun & $\$ 67 \mathrm{~m}$ & $"$ \\
\hline 10 & Oyo & $\$ 72 \mathrm{~m}$ & $"$ \\
\hline
\end{tabular}

Source: Field work, 2015

Table 5: Nigeria's Poverty Levels (2004-2011)

\begin{tabular}{|l|l|l|l|}
\hline $\begin{array}{l}\text { Poverty measure (in } \\
\%\end{array}$ & 2004 & 2010 & 2011 \\
\hline Relative poverty & 54.4 & 69 & 71.5 \\
\hline Absolute poverty & 54.7 & 60.9 & 61.9 \\
\hline Dollar per day & 62.8 & 61.2 & 62.8 \\
\hline
\end{tabular}

Source: Okafor, 2014.

Table 6: Frequencies

\begin{tabular}{|c|c|c|c|}
\hline Measures & $\begin{array}{l}\text { Observed } \\
\mathrm{N}\end{array}$ & Expected $\mathrm{N}$ & Residual \\
\hline 9.00 & 9 & 77.0 & -68.0 \\
\hline 25.00 & 25 & 77.0 & -52.0 \\
\hline 43.00 & 43 & 77.0 & -34.0 \\
\hline 96.00 & 96 & 77.0 & 19.0 \\
\hline 212.00 & 212 & 77.0 & 135.0 \\
\hline Total & 385 & & \\
\hline
\end{tabular}


Table 7: Test Statistics

\begin{tabular}{|l|r|}
\hline Chi-Square $^{\mathrm{a}}$ & 351.558 \\
$\mathrm{df}$ & 4 \\
Asymp. Sig. & .000 \\
\hline
\end{tabular}

a. 0 cell $(.0 \%)$ have expected frequencies less than 5 . The minimum expected cell frequency is 77.0 .

\subsection{Discussion}

From the evidence in table 1 there is now no doubt in this study that there is corruption in Nigeria. There has always been rhetorics of anticorruption crusade in Nigeria from the military regimes of the 1960-1990s and more since the present democratic experiment. With the pretences at anticorruption crusade no meaningful result has been achieved even since the Corrupt Practices and Other Related Offences, Act of 2000 was passed into law.

This is true because it is difficult if not impossible to reduce corruption if the government does not have the political will to curb it, ensure that the anticorruption agencies are not corrupt, punish corrupt officials, or reduce opportunities and incentives for corruption in vulnerable governmental agencies and parastatals (UNIAMIKOGBO, 2007).

The basic question should not be if there should be anticorruption agencies as is often debated in late developing democracies, but rather how to make them effective. Government must have the political will to ensure that anti-corruption agencies are independent, autonomous, secure from illicit influence, and have adequate means and knowledge to conduct their work.

To combat corruption effectively anticorruption bodies need a mandate broad enough to gather all relevant information, as well as being protected from political, and personal pressure, introducing at the same time strict rules of control over the interests, income, and property of the officials. Such political will, will also make it possible for the anticorruption agencies to have the financial, material, and other resources necessary to perform the required functions creditably (HOPKINSON; PELIZZO, 2006).

The political will to combat corruption is also the political will to pursue other issues necessary for good governance. Political will is essential for the unity of a 
DOI: 10.14807/ijmp.v7i1.382

nation and the happiness of the citizens. Strong political will is similar to Gowon's 1966 proposal for the unity of Nigeria. "Rule out disintegration, rule out unitarism, consider federalism with a strong centre, consider federalism with a weak centre, and if neither is acceptable, then construct an entirely new system unique to Nigeria".

This example implicates the fact that political will must reflect the character of popular democratic intervention, departing from pressure group or political manifesto rhetoric to becoming a significant voice, seriously posing the questions and views of people serving governance as a practical and immediate political possibility.

Political will is the critical starting point to halt and begin to reverse the deepening pauperization and disempowerment of the Nigerian people by the ruling classes and power blocs whose interests, run counter to the needs of the great majority (MADUNAGU, 2011; WILLIAMS, 2000).

Corruption due to lack of political will to curb it, has resulted in the abandonment of many projects in Nigeria. As reflected in table 2, the values of the abandoned projects mostly reflect government money stolen by corrupt politicians, bureaucrats, business people, and sundry others.

Corruption through contract inflation in Nigeria has grown from the 10 percent mark-up, or the "wee my own" syndrome in the 1960s and 1990s to 100 percent bribery of the moment (OMOTOSO, 2011). The present phenomenon has surpassed the Sierra Leonean corruption and bribery password of "put for me" (KPUNDEH, 1997). Significant others in Nigerian governance project are agitated at the high levels of abandoned projects which grew from 4000 in 1993 to 8000 in 2014.

Agbakwuru (2015) reports the Speaker of the Federal House of Representatives stating that "demons" could be responsible for abandoning projects like the Ajaokuta Steel Mill in Kogi state. The matter is as serious as that. Abandonment of huge projects leads to unemployment and poverty.

In a country where half of the federating states do not pay salaries as and when due, where the treasuries are cleaned up by political leaders, it would mean that the majority of the people would wallow in absolute poverty. Because of corruption and the lack of political will to combat it, absolute poverty rate grew from 55 percent in 2004 to about 63 percent in 2011 (OKAFOR, 2014). 
DOI: 10.14807/ijmp.v7i1.382

The confirmation of the G.7 Leaders of industrialized nations that the Nigerian government is facing severe handicaps due to lack of resources and mismanagement suggest that corruption is the mother of poverty. In the midst of poverty people elected to represent the people often waste time debating their pay, refreshments, meals, and sometimes, the age of little girls they can marry (OJIABR, 2012).

According to Fani-Kayode (2013) "Every Nigerian should bow his or her head in shame from today because what the senate did and seeks to do in the future by beginning the process to amend our constitution in order for it to cater for their filthy appetite, and godless fantasies of child molesters and sexual predators is sordid, ugly and unforgiveable.

To curb corruption in the chambers and ensure sound law making, parliamentary codes of conduct can help by providing a frame work within which members and the public can know what behavior is expected of members. They can serve as a means of encouraging the observance of high standards and of helping to develop a culture of compliance, openness and accountability and ensure that in the councils of government, members must guard against the acquisition of unwarranted influence, whether sought or unsought.

The level of corruption in Nigeria has risen so high that people now want to blame the "demons" for inflicting the epidemic on the country. Since the 1970s there have been accusations and counter accusations of corruption in the governance of Nigeria bordering on brazen acts of indiscipline in all its ramifications, misappropriation of public funds that went unchallenged, oil merchants and agents owing their massive wealth to illegal oil deals, contract inflation etc Agwunobi (2005).

While all these went on, salaries of civil servants and teachers remained unpaid, hospitals remained without drugs, schools without textbooks as states are unable to meat their statutory obligations (HOPKINSON; PELIZZO, 2006; ELAIGWU, 1985; NELSON, 2015). With a high Chi-square value of about 352, against a table value of approximately 9 , a strong positive relationship between political will and anticorruption crusade management was established. 
DOI: 10.14807/ijmp.v7i1.382

\subsection{Recommendations}

i) Elected and appointed government officials have the responsibility to discharge the functions of their offices without fear or favour for the benefits of the greater majority. The governments must enforce this.

ii) Political will is required in governance not only to curb corruption but also to pursue other legitimate goals. Contemporary political leaders can learn a lot from the political will of Gowon exemplified by his 1966 proposal. "Rule out disintegration; Rule out unitarism, consider federalism with a strong centre; consider federalism with a weak centre; where neither is acceptable, then construct an entirely new system unique to Nigeria". This is political will in action.

iii) Political will does not start nor end with the establishment of anticorruption agencies. The laws establishing them must be clear enough, and they must have the necessary autonomy to perform. Instances where the law stipulates penalties for people not declaring their assets, and none for those falsifying such information do not present a political will to curb corruption.

iv) Curbing corruption will require amending some aspects of the Nigerian Constitution such as the immunity clause that provides great incentive for corruption in high political places.

v) With over 8000 abandoned projects in Nigeria that requires about N5trn to complete, government should urgently revisit the issue as a major step in anticorruption crusade management. This is important because contractors, politicians and high level bureaucrats simply share mobilization and final contract fees and disappear, only for us to turnaround to blame "demons and witches" for the abandonments. It is doubtful if demons take bribes like most politicians do.

\subsection{Scope for further study}

Further study should examine the relationship between corruption and instability of government. This is crucial because there is empirical evidence that corruption undermines the legitimacy of government. 
DOI: 10.14807/ijmp.v7i1.382

\section{CONCLUSION}

The ugly challenge of endemic political corruption has continued to put countries into serious problems of underdevelopment, due to weak political will or the total lack of it to curb it. Corruption in whatever form is largely responsible for breeding a group of people in the corridors of political power frequently drenched in sectionalism, tribalism, despotism, favouritism, nepotism, incompetence, dictatorship, ineptitude, treachery, indolence, winning, dining, political rascalism and womanizing that bring about infrastructural decay, poverty and the worst, mismanagement of the affairs of a nation.

This exploration provided fresh empirical evidence to buttress the postulation that political will is a major instrument of anticorruption crusade management and the fact that the absence of it provides the incentive for monumental corruption deeply associated with abandonment of government projects and absolute poverty among the citizens of a nation. Political will to curb corruption is also the political will to pursue other national goals, like national unity. It is not equivalent to a pressure group approach or political manifesto rhetorics.

Rather it is a reflection of the commitment of the political leadership to take decisive actions. An example of political will is reflected in Gowon's 1966 proposal for national unity. "Rule out disintegration, Rule out unitarism, Consider federalism with a strong centre, consider federalism with a weak centre, and where none is acceptable, then construct an entirely new system unique to Nigeria". Through statistical analysis the study found a strong positive relationship between political will and anticorruption crusade management.

\section{REFERENCES}

ABUBAKAR, M.; MUSARI, A. (2015) Buhari to reopen botched $\$ 9.7 \mathrm{~m}$ arms deals with Zuma, Zenophobic attacks. The Guardian, v. 31, n. 13319, p. 1-2

ADEPOTUN, A. (2015) Nigeria Lacks Political Will to drive Digital Migration, THE GUARDIAN, v. 31, n. 13319 , p. 13

AGBAKWURU, J. (2015) Demons frustrating Ajaokuta Steel Complex - Dogara.

Sunday Vanguard, v. 24, n. 1479, pp:5,

AGWUNOBI, J. C. (2005) The Nigerian Military in a Democratic Society. Lagos, Logicgate Media Ltd.

AHMED, Z. (2015) Buhari, Global Anticorruption Watchdog to hold talks. Daily Sun, v. 10, n. 3165 , p. 16. 
ALLI, Y. (2012) Bi-Courtney to Contest Contract Cancellation - Why Bi-Courtney's N89.53bn Contract was cancelled. The Nation, v. 67, n. 2316, p.1\&3.

ALLI, Y. (2013) NNPC still owes Govt. N22bn, Says Sanusi. The Nation, vol. 8, No. 2695, pp. 1-2.

AMODU, T. (2015) Osinbajo, APC, misleading Nigerians on outstanding Govt debt PDP - Daily Sun, v. 10, n. 3150, p.6.

ANUFORO, E. (2015) Senate Probes Power Sector Under Obasanjo, Yar'Adua, Jonathan. The Guardian, v. 32, n. 13402, p. 1-2.

ASIKA, N. (2004) Research Methodology. A Process Approach. $1^{\text {st }}$ Edition Lagos. Mukusemu \& Brothers Enterprises.

BRINKERHOFF, D. W.; KULIBABA, N. P. (1999) Identifying and Assessing

Political Will for Anticorruption - Efforts. Washington, D.C.

CAMPOS, J. E.; PRADHAN, S. (2007) The Many Faces of Corruption: Washington, D. C. The World Bank.

CAMPOS, J. E.; PRADHAN, S.; RECANATITI, F. (2007) Where to Next? In J. E Campos and S Pradhan (eds) The Many Faces of Corruption. Washington, D. C The World Bank.

CONSTITUTION OF THE FEDERAL REPUBLIC OF NIGERIA (1999)

DAKA, T. (2012) Labour to Partner Reps. on Adoption of fuel subsidy report. The Guardian, v. 29, n. 12185 , pp: 47.

EMEWU, I. (2015) Auditor General Misinforming Nigeria on N183.7bn Audit - NDDC. Daily Sun, v. 10, n. 3216, p.46.

EFULU, J. I. (2015) Re: Precious Gbeneol Tenure At MDGs A Case of Alleged Monumental Fraud and Abuse of office. Daily Sun, v. 10, n. 3211, p.40.

ELAIGWU, J. I. (1985) The Military in Politics: An Afrocentric Perspective. Paper Commissioned for the Nigerian Airforce Day, 1985 Seminar at the Nigerian Institute of International Affairs, Lagos, 22 ${ }^{\text {nd }}$ April, 1985.

EMMANUEL, A.; OMOMIA, K. (2012) FG yet to Receive Subsidy Probe Report. Nigerian Pilot, v. 154, n. 2.

EMMANUEL, A. (2014) FG to Privatise Airports, Seaports, Roads. New Telegraph, v. 1, n. 23, p. 3.

ERIYE, F. (2012) $\$ 620,000$ Bribe: Police, House on Collision Course Over Lawan Probe. The Nation, v. 06, n. 2170, p.4.

FANI-KAYODE, F. (2013) A Nation of Perverts and Paedophiles. The Nation, v. 07, n. 2553, p. 14.

FOLA-SADE-KOYI, A. (2015) FG Mismanaged \$32.3bn Crude Oil Funds - Saraki, Daily Sun, v. 10, n. 3150, p. 6.

FOLA-SADE-KOYI, A. (2015) Senate Probes Customs, FIRS over N567bn illegal spending. Daily Sun, v. 10, n. 3210, p. 49.

GABRIEL, O. (2015) 18 States Bankrupt, Can't Pay Workers Salaries. Vanguard, v. 25, n. 62427, p. 25. 
HOPE, K. R. (1985) Politics, Bureaucratic Corruption and Maladministration in the Third World. International Review of Administration Sciences, n. 1, p. 1-6.

HOPKINSON, N.; PELIZZO, R (2006) The Role of Government and Parliament in Curbing Corruption in Central and Eastern Europe. In R, Stapenhurst, N, Johnston, and R, Pelizzo (eds) The Role of Parliament in Curbing Corruption. The World Bank, Washington, D. C. pp: 251-263.

ISA, A. (2014) 45000 Ghost Workers: Finance Ministry Refers Case to ICPC for Prosecution: New Telegraph, v. 1, n. 23, p. 6.

JABBRA, J. G. (1976) Bureaucratic Corruption in the Third World: Causes and Remedy. Indian Journal of Public Administration, v. 22, p. 673-91.

JEYIFO, B. (2013) Freedom of Information Act and Dictatorship of Corruption and Mediocrity (2). The Nation, v. 07, n. 2553, p. 13.

JOHNSON, M. (2006) Political Corruption and Public Policy in America. Monterey, Calf: Brooks/Cole.

KPUNDEH, S.; DININIO, P. (2006) Political Will. In R. Stapenhurst, Johnston, and R. Pelizzo (eds) The Role of Parliament in Curbing Corruption. The World Bank, Washington, D. C p. 41-48.

KPUNDEH, S. J. (1999) The Fight Against Corruption in Sierra Leone. In R. Stapenhurst and S. J Kpundeh (eds.) Curbing Corruption: Toward a Model for Building National Integrity. The World Bank, Washington, D. C p. $207-234$.

KPUNDEH, S. J. (1995) Politics and Corruption in Africa. A Case Study of Sierra Leone. Lanham, Md. University Press of America.

MADSEN, S. R. (2003a) Wellness in the workplace Preparing employees for change. Organisation Development Journal, v. 20, n. 5.

MADUNAGU, E. (2011) Dialectics of Structure and Governance (2) The Guardian v. 29, n. 11922, p.67

MALOGO, B. (2013) FG hands over successor Companies of PHCN to New Owners Sunday Sun, v. 10, n. 565, p. 3

MANUEL, J. A. (2003) Finding The Right Path. Finance and Development, v. 40, n. 3, p. 19.

MARSHALL, D. (2006) Afterword. In R. Stapenhurst, N. Johnston, and R. Pelizzo (eds) The Role of Parliament in Curbing Corruption The World Bank, Washington, D. C. P. 227-236.

MERNYI, D. (2015a) FG urged to recover $\$ 7.5 b n$ taxes from IOCs. Daily Sun, v. 10, n. 3161 , p. 55.

MERNYI, D. (2015b) We'll act on NEITI Reports, Buhari Assures. Daily Sun, v. 10, n. 3167 , p. 6.

NELSON, C. (2015) External Debt Profile overwhelms States. The Guardian, v. 31, n. 13324 , p. 1-2.

NWACHI, C. (2013) Is EFCC Winning the war against corruption? (4) Energy Today, v. 2 , n. 15, p.7. 
NWOSU, I. (2013) Reps to Probe Alleged Unremitted \$13bn Oil Revenue. Daily Sun, v. 10, n. 2761 , p. 5.

NZESHI, O. (2014) N295bn "Wasteful" Allocations uncovered in 2014 budget. New Telegraph, v. 1, n. 23, p.1-4.

OBASI, E. (2001) The Vision 2010 Agenda in Nigeria's Development, Mbaise, New Vision Publishers.

OBIJIOFOR, L. (2011) The tragedy of Dimej. Bankole. The Guardian, v. 28, n. 11853, p. 52.

OBIJIOFOR, L. (2013) Jonathan's Faltering Anticorruption Crusade. Daily Sun, v. 10 , n. 2590 , p. 50.

OBINNA, D. (2015) Buhari Okays sharing of N413.7bn LNG Proceeds to help states pay salaries. Directs CBN to package N250bn intervention funds. Daily Sun, v. 10, n. 3180, p.1-5.

OGUNDELE, K. (2012) Alleged N109m Pension Fraud. Court Rules Nov. 14. The Nation, v. 7, n. 2283, p. 7.

OGUNWALE, G. (2012) Governors accuse BPE of Fraud in Sale of PHCN Firm. The Nation, v. 7, n. 2283, p. 1-6.

OJIABOR, O. (2012) N1.3bn not enough for State House Refreshments, Meals. The Nation, v. 7, n. 2316, p. 1-3.

OJO, O. (2015) 8bn Currency Scam Court Quashes Bail Applications of 10 Suspects. Daily Sun, v. 10, n. 3165, p. 8

OKAFOR, F. O. (2014) Economic and Financial Inclusion Strategies for Arresting Systemic Poverty Amidst Robust Economic Growth in Nigeria. Paper Presented at the $4^{\text {th }}$ Accounting and Finance Research Association (AFRA) International Conference at Staff Development Centre, Abakaliki Nigeria, Tuesday, Nov. 04, 2014.

OLABIYI, L. (2015) Workers demand Prosecution of Briton Over Alleged $\$ 8.8 \mathrm{~m}$ fraud. Daily Sun, v. 10, n. 3165, p. 14.

OLADELE, B. (2015) N12b Currency Scam: N3.9bn Destroyed with Acid, Water, Court told. The Nation, v. 10, n. 3243, p. 1-4.

OLOWU, D. (1993) Government Corruption and Africa's Democratization Efforts. Corruption and Reform, v. 7, n. 3, p. 227-36.

OLUWASEGUN, V.; ANOFI, D. (2013) Is Anti-graft War on Course? The Nation, v. 8, n. 2701, p. 16.

OMONOBI, K. (2015) \$182m Halliburton Scandal Buhari orders preparation of case file, Sunday Vanguard, v. 24, n. 1483, p. 6.

OMOTOSO, K. (2011) Nigeria, An Abandoned project? The Guardian, v. 29, n. 11922 , p. 67.

OMOTOSO, G. (2013a) APC Calls for Probe of Massive Thefts, Corruption: The Nation, v. 8, n. 2701, p.1-4.

OMOTOSO, G. (2013b) Govt Owes us N1.3trn on subsidy, says NNPC. The Nation, v. 7, n. 2316, p. $1 \& 8$. 
ONANUGA, A. (2012) EFCC Arraigns 13 New Marketers over N4.6bn Subsidy

Fraud. The Nation, v. 7, n. 2270, p. 2.

ORINTUNSIN, J. (2014) Fed. Govt. Needs N5trn to Complete 8000 Abandoned Projects. The Nation, v. 9, n. 3080, p. 57.

OSAZUWA, J. (2015) A1tri diversion: Senate Quakes over Lamorde, Daily Sun, v. 10, n. 3216, p.12.

OSEHOBO, V. (2012) 67m Youths Unemployed - Minister Nigeria Pilot, v. 154, v. 2, p. 1-2.

RENO, W. (1995) Corruption and State Politics in Sierra Leone. New York, Cambridge University Press.

SIERRA LEONE GAZETTE (1992) The Prevention of Corruption Decree Supplement to No. 47, July 10.

SIERRA LEONE NEWS AGENCY (1992) Commission of Inquiry Special Weekly Reports.

SOLUDO, C. C. (2015) Ngozi Okonjo-Iweala and the Missing Trillions. Vanguard, v. 25, n. 62332, p 56-57.

TAIWO-OBALONYE, J. (2015a) Buhari Inherited Mismanaged Economy, say G.7 Leaders. Daily Sun, v. 10, n. 3161, p. 5.

TAIWO-OBALONYE, J. (2015b) Buhari Probes NITEL/MTEL's Sale. Daily Sun, v. 10, n. 3211, p. 5.

TAIWO-OBALONYE, J. (2015) Centenary City. Buhari meets with Abubakar. Daily Sun, v. 10, n. 3218, p. 5

UGURU, L. C.; IBEOGU, A. S. (2014) Effect of Bureaucratic Corruption and Lack of Public Accountability of Grassroots Transformation in Nigeria. African Social and Educational Journal. Nigerian Edition. v. 3, n. 2, p. 89-100.

UGWUANYI, E. (2011) Govt. to Probe Alleged Aviation Fuel Scam. The Nation, Tuesday Dec. P.15.

UKEH, O. (2015) How ex-gov. Orji, Wife, Son Squandered N474bn in Abia State. Daily Sun, v. 10, n. 3192, p. 51-52.

UKEH, O. (2015) Probe of NITEL/MTEL sale. Daily Sun, v. 10, n. 3218, p.17.

UNIAMIKOGBO, S. O. (2007) Management Imperatives of Economic Reforms.

Management in Nigeria, v. 43, n. 1, p. 20-27.

WILLIAMS, J. (2006) Building Parliamentary Networks. In R. Stapenhurst, N. Johnston, and R. Pelizzo, (eds) The Role of Parliament in Curbing Corruption, The World Bank, Washington, D. C p. 217-226.

WORLD BANK (1994) Sierra Leone. Public Expenditure Policies for Sustained Economic Growth and Poverty Alleviation. Washington D. C

ZACK-WILLIAMS, A.B, (1990) Sierra Leone. Crisis and Despair. Review of African Political Economy, n. 49, p. 23-33. 